\title{
Re-reading History: Alternative Truth in Jerusalem \& I by Hala Sakakini
}

\author{
Nehal El-Naggar ${ }^{1}$ \\ ${ }^{1}$ Department of English Language and Literature, Ain Shams University, Cairo, Egypt \\ Correspondence: Nehal El-Naggar, Department of English Language and Literature, Ain Shams University, Cairo, \\ Egypt. Tel: 20-100-141-8396. E-mail: nina13@aucegypt.edu
}

$\begin{array}{lr}\text { Received: April 1, } 2017 & \text { Accepted: April 17, } 2017 \quad \text { Online Published: May 30, } 2017 \\ \text { doi:10.5539/ells.v7n2p70 } & \text { URL: http://doi.org/10.5539/ells.v7n2p70 }\end{array}$

In the books you will find the names of kings.

Brecht

\begin{abstract}
Jerusalem \& I (1990) by Hala Sakakini (1924-2003) is a personal record of her life as experienced and lived in Jerusalem. This study focuses on Sakakini's re-reading of the history of Jerusalem prior to 1948 through her personal remembrances and recollections that she uses as a strategy for resistance. Hala Sakakini is a representation of a woman as a national subject developing a nationalist consciousness within the general flow of nationalism. This study attempts to explore the "alternative truth" rendered by Sakakini in her text. This "alternative truth" dismantles mainstream history written by the powerful. Palestinian women's self-narratives disentangle a number of correlated topics that convey an exploratory outline for approaching the topic of this study. Sakakini's writing in English was to carve a place for the experience of a female Jerusalemite voice. Her narrative is a lens through which reality is seen. What Sakakini is delivering to her readers is different from political traditional history; she is after the story of ordinary people. It is a form of oral history where she ponders to offer a socio-historical analysis and an ethnographic and geographic map of the land and the people, conveying another version of history, which subverts mainstream narrative. Hala Sakakini's quest is a quest for a lost place not a personal gendered quest; it is a collective discourse of belonging.
\end{abstract}

Keywords: Jerusalem, resistance, alternative truth, nationalism, memory, autobiography, history

\section{Introduction}

History has usually been the story of the conqueror or the great or the powerful. In his poem Questions From a Worker who Reads (1935), Bertolt Brecht writes:

Who built Thebes of the seven gates?

In the books you will find the names of kings.

Did the kings haul up the lumps of rock? (Note 1)

Jerusalem \& I (1990) (JI) by Hala Sakakini (1924-2003) is A Personal Record, as she calls it, of her life as experienced and lived in Jerusalem. This study attempts to explore the "alternative truth" rendered by Sakakini in her text. This "alternative truth" dismantles mainstream history written by the powerful. It focuses on Sakakini's re-reading of the history of Jerusalem prior to 1948 through her personal remembrances and recollections that she uses as a strategy for resistance. It is what Thompson (1966) termed "history from below". The use of the words Personal Record, along with Jerusalem, to document her lived experience, has artistic and strategic purposes. The delivery of the personal and the subjective embrace a collective significance. The "self" in her text is not individualistic in its attitude because "Consciousness is contextualized rather than privatized" (Smith, 1993, p. 396). She is trying to divulge her personal life as much as she pursues to describe a collective identity and shared life experiences in the city of Jerusalem. The personal "I" is changed to be the communal "I" of all Jerusalemites. She is articulating a group identity. Jerusalem \& I is not a subjective petite histoire of Hala and her family, but a collective narrative representing of all Jerusalemites, through Hala, the individual. The city is the center around which all events revolve and develop. What Sakakini is delivering through her individual memory is inclusive of a collective representation. Hala's story, as a little girl then as an adult young woman, of 
a particularly experienced past in Jerusalem, is inseparable from her sense of community and collective memory of her people. Sakakini's experience in Jerusalem fueled her sense of portraying what she has lived through:

As we walked along we started to notice old familiar sights: the shoeshine shop where as children we often sat on high chairs and watched with interest how our old Armenian friend went about polishing our shoes. The shop was now in ruins. Further along, on the opposite side of the street, we saw the place where a delicatessen used to stand. Abu Shafiq was famous for his delicious Arabic sweets. Then ahead of us we saw the narrow two-storey building at the street corner. There used to be the little fruit shop that belonged to Jawdat al Amad, who sold along with the fruit the local Arabic newspapers Falastin, Ad-Difa and others. In the old days we would pass Amad's shop as we came down the street from Fast Hotel, then turn round the corner and there at the bus stop take No. 4 to Katamon and home. (JI, XII)

This is how she describes every corner of the streets and the places where she has lived, among other fellow Jerusalemites. She is injecting life into her narrative by relating to real people with names. Moreover, she is referring to a local newspaper called Falastin, the name of her country that was lost to be replaced by the Jewish State. Sakakini's writing in English was to carve a place for the experience of a female Jerusalemite voice. Her narrative is a lens through which reality is seen:

At last we started going uphill on the stretch of our journey. With some relief we saw the two Tleel houses standing unchanged as though to serve as landmarks. ...we came to the twin Murcos villas, which we also found unaltered. Between these two villas we caught a glimpse of our house for the first time. ...We quickened our pace past the Damiani house. ...We turned right and walked along our own familiar tree-shaded lane, round the Damiani garden, past the Homsi apartment building where my grandmother and uncles, the Awads, the Sfeirs, and the Budeiris used to live, past the third Tleel house, our next-door neighbours, and at last we were there. We had reached our destination. It was a sad moment. (JI, p. XIV)

She is bringing in evidence of people who actually lived in these houses. Definitely, Sakakini is participating in reproducing the story of a whole nation, not of a woman. It is not a gendered text. She is part of a once upon a time social, historical and political reality. Moreover, she is developing a comprehensive unification with reality. Although Sakakini's text is written in English, yet it is ignored in the West, maybe due to the fact that she is not playing into Western prejudices. In his reflections on Arab cultural production as restricted literature, Edward Said (1995) argues, "truly first-rate literary work ... has gone unnoticed ....as if ...prejudice [was] a blockade designed to interdict any attention to texts that do not reiterate the usual clichés about Islam ...sensuality" (p. 99). Hence, significant scholarship on Arab women's autobiography, which does not conform to Western prejudices, is scarce. Women's autobiography is a passage from life to self-writing. Additionally, Palestinian women's self-narratives disentangle a number of correlated topics that convey an exploratory outline for approaching the topic of this study. What Sakakini is delivering to her readers is different from political traditional history; she is after the story of ordinary people. Sakakini is writing the "self" to deliver the "collective", hence offering an "alternative truth" to dismantle mainstream historical records.

\section{Writing the Self: The Personal to the Collective}

For an Arab woman, regardless of her age, social standing and religious affiliation, autobiography is a challenging practice because society "values a sharply defined separation between the inner and the outer" (Milani, p. 2). Private life with its personal feelings and beliefs should stay unreachable and thus hidden within the precincts of a well-guarded terrain. The implication of being a genre of self-exposure explains why it is not a much-developed genre amongst women. Besides, Smith \& Watson (1998) widen the understanding of autobiography to be a kind of a documentation of cultural practices, which in fact could be regarded as an identity practice. Some call it an "outlaw genre" (Smith \& Watson, 1998) because it recalls experiences, which are not identical with the prevailing culture or history: “...we would set out on foot to the open fields on the outskirts of Jerusalem where we would choose a comfortable rock to sit on or an olive tree for shade ...[and]...in this way we came to know and love every part of our country" (JI, pp. 34-35). What she is recalling is an off-record remembrance that proves the existence of places with people living in it. Definitely, "The use of personal history as an illustration of the troubles of an entire community ...transforms ....autobiographies ...into literature" (Watts, p. 125). Unquestionably, "to speak as one group, to speak for a group,” (Lionnet, p. 99) offers appeal to readers because it breeds a constant connection with the collective pains, aspirations and hopes:

Ever since we were children we have felt a deep love for our country. This spirit of patriotism is mainly due to the way we were brought up at home, but also partly due to the political circumstances in the country. There was always the great danger of Palestine being lost to the Jews. As children we were often present when such subjects as the continual inflow of Jewish immigrants into Palestine were anxiously discussed at 
home. (JI, p. 56)

Sakakini brings together in a very spontaneous manner the public-private construct, endorsing an identity that goes beyond her as an individual to include an all encompassing national and political reality. It coincides with what Latifa Al-Zayyat (1996) professes:

One can only find one's self by initially losing it into a much wider issue than one's own subjectivity, into a reality bigger than one's own-we do not attain our true selves unless the self first melts into something outside the limits of its ego. (p. 57)

This is what Sakakini has done by rendering a text that identifies with the experiences of a whole people. As a Jerusalemite, she is fully aware that being an author or an autobiographer she is driven by historical forces that make her as an individual (Saldivar). Hence, reading her personal record involves more than an aesthetic judgment of the writing, since the text is embedded in the real world of the people she is writing about:

My father, Khalil Sakakini, was born on January 23, 1878, of Arab parents. My mother, Sultanah Abdo, was born on December 19, 1888, also of Arab parents. Both the Sakakinis and the Abdos lived in the Christian Quarter in the Old City and were what we would call "stone neighbours" in Arabic, that is, they were living in adjacent houses. The two families were the owners of the houses they lived in, not tenants, and they had been neighbours for generations. (JI, p. 1)

She is asserting that her ancestors had lived on this land for generations and owned the houses they lived in. Her self-narrative has to be read as a historical record, which raises questions that are inextricable from self-understanding; the self, being a participant in the life of her people - the self and the collective become one. Hala's personal life in Jerusalem, and its surroundings are set against the turbulent national and political life of her people. Al Nowaihi maintains that there are two important processes in autobiographies; remembering and then the interaction of the private and the public that are human realms put into dialogue with each other. Furthermore, Jerusalem \& I is not only a personal narrative but also a "national allegory" (Ahmad) where she depicts a "situational consciousness" (Jameson, 1986), which includes the personal and the socio-political status quo, and in which the telling of the personal story and lived experience eventually engages the collective, thus rendering a sense of a collective identity. Notably, theories of collective remembering show individual memory as involved in the process of re-creating communal historical reality:

A constant source of irritation for the Arabs was the hypocrisy of the British policy in Palestine. On the one hand the mandatory power claimed that it was protecting the rights of the indigenous population of the country, while on the other hand it helped thousands of foreigners from all over the world to come and settle on the land. The Arabs felt they were being cheated. This deceitful policy provoked their wrath and indignation. They expressed their feelings in rebellions which flared up in all parts of the country at short intervals. The mandatory power used harsh and brutal measures to put down these rebellions. The Arabs of Palestine grew bitter and more defiant. (JI, p. 56)

Halbwachs upholds that autobiographical memory is always embedded in other people. The individual recollects by engaging himself in the perspective of the group, and the memory of the group achieves and expresses itself in the recollections of the individual. He explains such interchange: "While the collective memory draws strength from its base in a coherent body of people, it is individuals as group members who remember" (p. 40). Thus, all memories assume a collective value that is shared by everyone of the community, where the personal story that includes an individual experience, embraces the collective self of the people:

For several weeks during summer of 1934 Jerusalem was an exciting place to be in, at least for us children. Every night at about eight we would go out to our verandah and look up at the sky to see fireworks unfolding. The occasion for this celebration was the Arab Exhibition, held in the white, palatial Awqaf building at the bottom of St. Julian's Way, across the street from the Mamillah cemetery. ...The place was always crowded with happy people, and there was so much to see. (JI, pp. 49-50)

Evidently, individual or personal remembrances procreate a collective insight. Sakakini is trying to bring in her personal record, collective and public remembrances, which were lived by real people. She is referring, time and again, to actual historical events found in formal historical records that she, amongst fellow Jerusalemites have lived and experienced in an attempt to voice the silences and gaps in formal history that Jerusalem as an Arab city existed and had a life of its own. Moreover, Chatterjee professes that the political history of any times hold together the memories in the stories, that are lived by the narrator, and are rendering it as one single narrative ( $\mathrm{p}$. 138). Hence, personal memory is deliberated on the basis of its socio-historical dimension. Recalling places with specific incidents and people act as identity-markers for nations, territories and social groups, and serve goals of 
remembering a once-upon-time nation. Unquestionably, the act of self-writing goes beyond the personal to involve the communal whole. For instance, when English soldiers "would stop dignified Arab pedestrians, especially the older men, and force them to pick up nails from the streets" (JI, p. 60). In this way, Sakakini's personal record is not only her own. It is connected with what was happening in Jerusalem and its people. Hence, it is more than a subjective concern. She reminisces and records what seems to be personal and particular, yet it is related to the general. The form of the narrative is also challenging as it alternates between narration, letter writing and diary entries. This helps Sakakini in the inclusion of the personal and the collective:

A large variety of goods from different Arab countries was on display-exquisites brocades from Syria; thick, woolen blankets from Iraq; leatherware from Egypt; perfumes and confectionary from Lebanon; heavy camelhair abayas and light black ones from Iraq. Then there was the local products of which we were very proud: the colourful, sweet-smelling balls of soap produced in a Nablus; the mother-of-pearl goods from Bethlehem; the rough, hand-woven woolen mats from Beersheba and Gaza: the handwoven towels from Majdal: the olive wood articles made in Jerusalem. (JI, p. 50)

Moreover, Hala, as a woman, is the guardian of her culture with its values, virtues and all its nuances. She is including many of the local dishes in an attempt to verify the existence of her people, who had a life:

It was the famous dish of our countryside - Musakhkhan — roasted chicken placed on tabouny bread soaked in olive oil and covered with a lot of onion cut in thin slices. (JI, p. 36)

While in Nablus we had to have that famous local specialty, knafeh, which Dr. Dides Sr. ordered for us at one of the sweetshops in town and which arrived at the house sizzling hot in a round, flat tray. (JI, p. 46)

In bringing these day-to-day details, she is ascertaining the existence of a lived culture with its traditions and food, as opposed to foreign domination and invasion. Her story that comprises constructing a sense of national identification seeks to inscribe an inclusive story that binds the collective. Sakakini renders Jerusalem as a concrete representation of a land with real people who have been living on it and through it. They have their own culture including their daily practices withtheir own traditional food, which at times were related to specific occasions like Easter and Ramadan amongst many others:

Making the traditional sweets—Ka'kouma'moul—for Easter was quite a social affair (JI, p. 43).

It was in the Old City more than anywhere else in Jerusalem that Ramadan made itself felt. ...Everywhere the festive air was manifest. Even the smallest shop was lit up and decorated. But the greatest attraction was the sweetshops. These were stacked with large, round trays of delicious Arabic sweets-karabeejhalab, Burma, baklawa, knafeh, zunoud-es-sit, asabe'zeinab, kolwushkor, mutabbaq, and of course atayef. The latter are made only in Ramadan. ... Ramadan without atayef is unthinkable. (JI, p. 84)

Furthermore, Sakakini refers to her brother Sari's acquaintance, Kermit Roosevelt, a foreign correspondent who "had recently published an article in the Reader's Digest under the title "The Arabs Also Live There" dealing with the Palestine question" (JI, p. 77). She is quoting a living witness, who is not a Palestinian and who had an article published in an English paper documenting the existence of the Palestinian people. She also remembers events that were experienced by the whole community. The event where she tells her readers that they attended "concerts given by the Palestinian Philharmonic Orchestra at Cinema Edison in Jerusalem" (JI, p. 78) indicates that there was a Palestine having its own Orchestra. Sakakini, as a Jerusalemite, does not have independent subjectivity as a woman. The anti-British and anti-Zionist riots which broke out in 1929 delivered a spur for spontaneous activism that formed the main framework of women's political action (Khalifeh), free of any gendered agenda; the nation comes first:

In those turbulent years, the thirties, the Arab women of Palestine were in the centre of the political scene, Aunt Melia, for one, was very active. With great enthusiasm and national fervour she participated in demonstrations and protest marches. ...Quite often rough encounters with the police took place and the Arab women showed courage and presence of mind. (JI, p. 28)

Promoting feminist issues must take a back seat given the atrocious scale, which the nationalist dilemma has assumed. As women fighting the upcoming occupation, they also fight against limiting traditional values instilled in people's consciousness. Liana Badr admits, "My struggle for emancipation as a Palestinian is inseparable from my struggle for genuine liberation as a woman; neither one is valid without the other" (Shaaban, p. 164). Thus, Sakakini's personal record evolves as a strategy for resistance giving way to woman's voice to be part of the agenda of the collective national struggle. 


\section{Remembering as a Strategy for Resistance}

"resistance is encoded in the practices of remembering and writing"-Mohanty

In nations where land is lost, women do not identify themselves as separate from their collective national identity. They do not have a subjective identity. In Jerusalem and I: A Personal Record, Sakakini's memory becomes a historical national archive, where she reminisces to etch her lived story within collective national history, thence subverting mainstream history written by the powerful to deliver a different reading. This retrieval of a woman's memory in Jerusalem and I serves to document what is absent from formal history or what authority mutes. Hala's Personal Record, as she calls it, serves to illustrate how her scope of lived experience - that is not included in the mainstream male national narrative - constitute a reservoir for resistance for a collective national struggle. Frantz Fanon advocates that writers of struggling nations "use the past with the intention of opening the future, as an invitation to action and a basis of hope" (qtd. in Tzoreff, p. 77). Her text abounds with such remembrances:

The Alamis had a winter house in Jericho. (JI, p. 40)

Aunt Froso Bazouzi, Father's married sister, lived in the Christian Quarter in the Old City of Jerusalem, in the same house in which my father was born and where he spent his boyhood, youth and early manhood. (JI, p. 47)

She is remembering places where people actually lived and owned their houses. Who can deny that these people were living in these places? Jerusalem and $I$ is a re-writing of the city through the reminiscence of lived events and incidents that make stories:

One hot summer day in 1927, just after lunch, when everyone was having his afternoon nap, the great earthquake in Palestine took place.

That year Aunt Melia came to live with us as the room which she used to occupy in my grandfather's house in the Old City had been badly damaged by the earthquake.

The house we moved to was an apartment in a large building which belonged to a Mr. Kawas of Bethlehem. (JI, p. 6)

Time and again, she is recollecting a real historical event that they lived through and had consequences on the lives of the people - the 1927 earthquake. Through such individual personal records or memories, the whole community is expressed. Sakakini is not an individual but a representative of a subjugated collective self, who is fueled by her past lived experience, as a Jerusalemite, becoming aware of her political identity and also aware of her responsibility towards her people. Her personal record becomes a collective memoir rooted in other people because human memory relies on collective sources for sustenance (Halbwachs). The regularly engaged method in Sakakini's recollections is to record daily events with real people who are the main actors of her narrative:

Speaking of the southern suburbs of Jerusalem I now remember the Arab villages in the vicinity-Battir, Walajeh, Beit Safafa, Malha, Sharafat, Beit Jala, El-Khader-which used to provide us with fresh vegetables and fruit throughout the year. When I think of Battir I recall the peasant women with straight backs that used to stop at our house in the early morning in summer carrying on their heads round, flat, dark-brown baskets heaped high with those purple, longish egg-plants of Battir, ... The names of Walajeh and El-Khader bring back to my mind the sweet "jandaly" grape which was our favourite as children. (JI, p. 106)

Women writers, who lost their land or are losing their identities in exile, or under occupation, or even those who are still living on their land but actually lost it, like Native Americans and Liberians versus Americo-Liberians are unswervingly determined to keep their memories alive with the stories of the lives that they once lived amongst other fellow citizens. This they achieve through various means; one of which is the form of Sakakini's personal record where she tells the story of her land as she and her people once experienced it, giving it a kind of vividness as if it is still there:

I remember vividly the early morning scene ...when peasant women, proudly carrying their wares on their heads, would arrive at our house. Father would help them put down their heavy baskets and they would then sit down on the floor ...invite my mother to pick her choice of fruit and vegetables at leisure... While the business was going on ...[they] ...would ...air their family grievances, and Mother would ...encourage and give advice when necessary. Their faces and personalities became familiar and we knew them all by name. (JI, pp. 106-107) 
Evidently, through recollection, Sakakini never loses the thread of her memories, because she is committed to accurately remember the stories of her daily life and her people's with all its idiosyncrasies in order to communicate, and never lose, her culture which is her national identity. Smith (1998) claims that self-narrative with its subjectivity develop to be the ground for resistance (p. 435). Sakakini's text "assumes the guardianship of personal and communal stories that face the danger of fading into oblivion in the shuffle of history" (Seyhan, 144). In her own way, Sakakini is "reconstructing the social history" (Chatterjee, p. 139) of her Jerusalem. Sakakini portrays the place, as she has, amongst her fellow Jerusalemites, experienced it:

In 1936 the General Strike in Palestine took place. For six months all Arab shops were shut, all traffic stopped, all schools closed. A strict boycott of Jewish shops was imposed. ...Everywhere policemen with steel helmets. ...Armoured cars patrolled the town. (JI, pp. 56-57)

Furthermore, stories are recounted and thus recorded to tell about the shared habits and customs of the Palestinian Jerusalemites and the common realities behind the different life stories. The ceremonies and festivities of their homes are there in the text: public events, marriages, births and deaths along with devastating events. Accordingly, the text is documenting for the lives of women in their homes, a record that is always absent from formal history. Moreover, it is this space inhabited by women that is witnessing the daily on goings of people's life in Jerusalem:

Sometimes young peasant men would come carrying huge baskets of fruits. Their eyes were bloodshot and their faces pale as if they had not slept for days. Mother would make coffee for them and father would offer them cigarettes. (JI, p. 58)

Unquestionably, she is nostalgic about her once upon a time past and compares it to her oppressive present:

And what ugly, huge tenement houses have sprung up in what used to be open countryside to the south of Jerusalem. Those rolling hills once strewn with olive trees, where we used to picnic as children, have become congested areas. Immense, featureless cement structures fill the wide valley where we used to roam in soring picking red anemones. Everything now looks disorderly, so utilitarian, so impersonal, so shabby. By putting up these houses, Israel has failed to create new neighbourhoods, it has only provided new immigrants with places to dwell in. (JI, pp. 105-106)

Additionally, loss imparts the city with a mythic quality rendering an eulogistic account of the past where "we would set out on foot to the open fields on the outskirts of Jerusalem where we would choose a comfortable rock to sit on or an olive tree for shade" (JI, p. 34). Descriptions of nostalgic ponderings act as an abode of the past and the present, maybe with no future. She draws her past life as an untouched, intact simple one, against the havoc, loss and defacement of the present. A "knowledge of past and present is...produced in the course of everyday life ... [and] encapsulated in anecdotes that acquire the force and generality of myth" (Popular Memory Group, p. 210). She has a yearning for the peaceful past that is set against the cruel life of dispossession and dislocation. Images and shadows of the past, in autobiographies or personal records, become effective in sustaining a tolerating sense of the self. Such intense reminiscence provides a refuge of security and a place where we can recollect fleeting moments of peace and serenity. This is a re-visit to the past as it once was and as we wish it to become. Intense emotions are carried within all the tiny details that she gives life to in her stories:

Life moved at a dignified pace. Katamon, Baq'a, Tori, Lower Baq'a, Namamra, Talbieh, were all Arab quarters, and the traditional Arab courtesy marked the behaviour of the people. Alas, this is no more so. In 1948, all these Arab quarters of Jerusalem were taken over by the Jews and have consequently lost their character. They are part of what is now called "West" Jerusalem and the new inhabitants who have come from all over the world are incongruous, heterogeneous lot. (JI, p. 104)

Sakakini's recollection of communal sentiments, group passion and daily-lived experience in Jerusalem is an act of nationalism, which "is an assertion of belonging to a place, a people, a heritage" (Said, 1990, p. 359). Evidently, personal and family narratives support the collective memory that functions essentially in the definition of a nation. Thus, Jerusalem becomes Sakakini's "realm of intimate space ... the exterior spectacle that helps intimate grandeur unfold" (Bachelard, p. 192). Jerusalem becomes the protagonist of her text.

\section{Jerusalem: The Nation as the Narrative}

Bhabha's theory of nation and narration is most clearly manifested in Palestinian autobiographical literature, whereself-writing becomes a narrative of the nation:

Sometimes I longed to be able to write a novel and make Jerusalem its locale. I wished I could capture the mood and the spirit of Jerusalem, describe its houses and streets and the lives of its people. I liked the natural reserve and dignity of the Jerusalemites, their sense of honour, their genuineness, their decency. I 
was proud to be one of them and to belong to this ancient city. (JI, p. 103)

With Sakakini, personal memory recollections become identity pointers for the community and help in the collective goal of retrieving the nation that was, since the concern with national identity is noticeable. Thus, helping in the strengthening of the future nationalist projects. In her text, Sakakini renders Jerusalem, the city, as the narrative or the protagonist, without which there will be no text. The characters and events introduced in the text are there because they contribute to the life of the city:

Speaking of fairs, I recall another event that took place annually in Jerusalem and which we found exciting. It was the traditional one-day picnic in Mar Elias, a Greek Orthodox monastery on the road to Bethlehem. This occasion fell on a day in summer and people, mostly from the Old City, went out in droves to the rolling countryside around that monastery south of Jerusalem. (JI, p. 48)

The city is the central axis around which her self-narrative and others' revolve and evolve. Without Jerusalem, all narratives become lifeless. Autobiography for Sakakini is not a "way to define the "I"' (Golley, p. 74) but to merge the story of the self with the story of the city, thence the nation. Jerusalem is the protagonist of her text. The self-narrative is primarily about Jerusalem and the author's life, amongst others, as lived and experienced in the city, prior to 1948. The relationship between fellow Jerusalemites is established through the geographic location and real events. Sakakini is recording life in the city of Jerusalem with all its minutest detail:

There is another occasion that I always connect with Aunt Froso and her family. It is the Sitna Mariam feast in August. ...The atmosphere was very much like that of a fair—gay, noisy and colourful. (JI, p. 48)

Another event of the same nature was the Moslem Nabi Musa feast, which always coincided with the Eastern Holy Week. Peasants from all over Palestine took part in it and made it most colourful. ...At the head of the procession would be the Mufti of Jerusalem riding a horse and carrying the banner of Nabi Musa. A huge crowd would have gathered just outside St. Stephen's Gate to welcome them back. (JI, p. 49)

Undoubtedly, Sakakini, similar to other Palestinian writers, tried to convey the Palestinian identity through land rhetoric, merging with their physical space, which evolved as a key pattern for resistance. Moreover, their close association with their land in their writings enhanced their nationalist aims; thus asserting their Palestinian identity. Feelings of deep national belonging to ones land is evident throughout Sakakini's text:

When I think of these Arab villages I cannot help but feel nostalgic for the way of life in Jerusalem prior to 1948. It was a personal, human relationship that connected us Jerusalemites with the villages surrounding the city. (JI, p. 106)

In Sakakini's text, her ancestral land develops as a binding story for all Palestinians. After nineteen years of absence and after the 1967 war, Hala and her sister return to their hometown and to their house in Katamon, which has become occupied. They try to reconnect with their once upon a time house and city. This revelatory moment releases a panoramic vision of reminiscences of a once upon a time lived space. The encounter resembles that of meeting an old dear friend:

It was a sad encounter, like meeting a dear person whom you had last seen young, healthy and well groomed and finding that he had become old, sick and shabby. ...All through the years since 1948, we had lived in exile, away from our Jerusalem. (JI, p. XI)

Evidently, Jerusalem is the staple of Sakakini's personal record, and the question typical of the genre of autobiography is modified from "Who am I, how did I become and what I am now?" [into] "Where am I and where do I belong to?" (Enderwitz, p. 53). Through the reunion to this memorable setting, she recollects past events, develops this feeling of nostalgia that is very common in Palestinian self-narratives. During the Arab fair that was held in Jerusalem Hala reminisces:

Leisurely winding our way through the throngs in the large halls, we would feast our eyes on the many articles everywhere in view. There was enthusiasm, and a strong feeling of patriotism, in the air. Everybody seemed elated. Even as children Dumia and I were keenly aware of this. Now I know why people felt the way they did at the time. It was the joy and pride of belonging to the Arab nation. For them the Exhibition had a symbolic value. It was material evidence that Palestine was an integral part of the Arab world. (JI, p. 50)

She is stressing the fact that this land had people living on it where they shared public and national events and "Everywhere you could see the Arab flag with its green, red, white and black colours fluttering high above the heads" (JI, p. 49). It had its own flag. In Jerusalem and I, land is literally lost and becomes out of reach, yet Sakakini cannot but reflect on it as a symbol of stability, rendering a nationalist narrative while deliberating "I 
cannot help but feel nostalgic for the way of life in Jerusalem prior to 1948" (JI, p. 106). Moreover, if autobiography develops to be a "resistance to mutilation ... to loss" (Gunn, p. 76), then Sakakini's personal record turns out to be, "a learning how to walk again ... [and] walking again requires a new sense of the ground, a trust that the ground will hold up and not give way. But what happens when it is the ground itself that gets lost, not simply a leg to stand and walk on?" (Gunn, p. 76). Evidently, although she has suffered what Gunn refers to as "loss" and "mutilation," yet she remains fighting back through this never-ending sense of belonging. She has this latent kind of resistance, relentlessly struggling to retrieve her land. She is charting to the reader the minutest details of her city. What she renders is a kind of a "cognitive mapping" (Jameson, 1988, p. 353), where she re-assembles her memories, as if they were never disturbed, and are still living within her, not only as an individual but also as representing of her people:

From the responsible body-Al-Majless el-Islami el-A'la-our school had obtained permission for the students and the staff to visit the Dome of the Rock and Al-Aqsa Mosque. ... we walked past the railway station, then down the hill to Birker-es-Sultan, then up the hill in the opposite direction to Nabi Daoud, and then along a stony, dusty path close to the city wall until we reached Bab-el-Magharbeh (The Dung Gate) from where we entered the Old City. Through the narrow, dirty lanes of Al-Magharbeh quarter (which, by the way, has been completely erased by the "authorities" since the Six Day War) we made our way to the Dome. (JI, pp. 19-20)

This verbatim city mapping, yields a familiar reading of the physical topography of Jerusalem fused with the make-belief association of the individual to the actual circumstances of existence-although it is a past existence only brought alive through memories:

From Beit Safafa kindly, round-faced elderly woman used to bring us freshly-picked young marrows, cool and moist with dew, their yellow flowers still attached to them. In spring, a tall, lean woman from Malha used to get us... those large, velvety green almonds,... I think it was also from Malha that we used to get the hard, green (but ripe) pears called Abu Hassweh, which Aunt Melia was especially fond of. From this region too came the small, yellow apples called Sukkari. When June ...came round, Im Salim - a small, gnarly old woman from Beit Jala - would get us wonderful Mistkawi apricots hand-picked one by one from her own orchard. (In Winter this same woman brought us home-made wine and vinegar in big flasks.) (JI, p. 106)

Obviously, the reader can easily track Sakakini throughout her recollected account of her day-to-day world as living the moment with all its details. For her, the aspects of her daily life with all its lived experiences, among her fellow Jerusalemites, are a symbol of collective unity, because land and life become one inseparable practice, where one cannot understand the one without the other:

We went out of the Old City through St. Stephen's Gate and walked down to the Garden of Gethsemane. From there we climbed up a steep hill to the Church of the Lord's Prayer on the Mount of Olives where we spent some time reading the Lord's Prayer written in different languages on the stone wall of the church. ...By the time we reached Damascus Gate we were all very tired. (JI, pp. 19-20)

Her text is like a chronograph recording all of these timely lived experiences very accurately, adding to it a spatial element of the city to become her basis for identity formation. This merging of time into space and vice versa is what Bakhtin calls the chronotope where time is materialized in space, in which the "basic assumption is the idea that narrative texts are not only composed of a sequence of diegetic events and speech acts, but also - and perhaps even primarily — of the construction of a particular fictional world or chronotope" (Borghart, p. 4). This helps recognize that Sakakini's recollections of time and space are grounded in an emotionally experienced world:

In the literary artistic chronotope, artistic and temporal indicators are fused into one carefully thought-out, concrete whole. Time, as it were, thickens, takes on flesh, becomes artistically visible; likewise space becomes charged and responsive to the movements of time, plot and history. The intersection of axes and fusion of indicators characterizes the artistic chronotope. (Bakhtin, p. 84)

The meticulous and accurate portrayal of landscape is more than just an account. It is the process through which Sakakini manifests time in space. The chronotope of the place is intensely permeated with the sociopolitical inferences:

Again it was in the company of Aunt Melia, who had many Moslem friends. We sat on a high spot on the spot north of St. Stephen's Gate. ...Everywhere you could see the Arab flag with its green, red, white and black colours fluttering high above the heads. The scene filled us with enthusiasm and pride. Every now 
and then strong young men would link their arms together and, forming circles, would start dancing the "dabkeh" and singing. ...Although the Nabi Musa feast was supposed to be a religious occasion, it was in fact a national day in which all the Arabs of Palestine, Christians and Moslems alike shared. (JI, p. 49)

This "inherent connectedness of temporal and spatial relationships" (Bakhtin, p. 84) "denoted by the term "chronotope" is tantamount to the world construction that is the base of every narrative text, comprising a coherent combination of spatial and temporal indicators" (Borghart, pp. 3-4). This is a kind of land rhetoric that enhances nationalist aims, and provides a genius loci asserting Palestinian identity:

In 1936 the General Strike in Palestine took place. For six months all Arab shops were shut, all traffic stopped, all schools closed. A strict boycott of Jewish shops was imposed. No Arab rode a Jewish bus or went to a Jewish cinema or café. ....Armoured cars patrolled the town. (JI, pp. 56-57)

Sakakini's "scraps, patches and rags of daily life" (Bhabha, p. 145) is a kind of a re-counting of her daily life in Jerusalem as she has lived it. Evidently, Sakakini's narrative, which is rendered in the form of a personal record "functions as a kind of nationalism" (Smith, 1998, p. 437). It links Hala with her people at a very important historical instant in the history of Jerusalem in particular and Palestine in general:

Every day at six o'clock in the evening we had to be home as there was a curfew on in Jerusalem. Around that time we used to stand in our verandah and watch people as they hurried home; (most would be carrying flat, oval-shaped "bita" loaves fresh from Frank's bakery at the eastern end of our street). At six o'clock the streets were all quiet, empty and forsaken except for policemen walking in pairs and carrying guns. (JI, p. 57)

It is a form of oral history where she ponders to offer a socio-historical analysis and an ethnographic and geographic map of the land and the people, rendering another version of history, which subverts mainstream narrative, hence delivering what Thompson called "history from below".

\title{
5. History from Below
}

\author{
Every page a victory. \\ Who cooked the feast for the victors? \\ Every ten years a great man. \\ Who paid the bill? \\ So many reports.
}

So many questions.

Brecht

Edward Thompson transformed Brecht's thought into action when he came with the concept of "history from below" (Sharpe). Earlier, in 1932 the French Lucien Febvre first used the phrase "histoire vue d'en bas et non d'en haut" in Annales d'Histoire Economique Sociale (qtd. in History from Below in TLS) which is history seen from below and not from above. What counts is people's history that is the historical narrative of everyday life from the perception of common people not the powerful. It is the experiences and understandings of the masses as actually lived, not of great men. Sharpe deliberates on the usefulness of this technique, which attracted people with different and variant ideological and religious affiliations to write history. The importance of writing history from below is greater than merely offering writers and historians with an opportunity to show that they can be groundbreaking. Such approach places a social event within its full cultural context to be studied not only from a descriptive point of view but from an analytical perspective as well (Sharpe):

The soldiers went into the kitchen and pantry and with their bayonets pierced the sacks of flour, sugar and rice ...they destroyed everything... pulled out the lingerie and, amidst much jeering and foul talk, examined it piece by piece. Whatever they fancied they did not hesitate to pocket, the rest they threw on the floor and trampled on it. When they finally left, the house was in a sad state. For Aunt Amalia and her family this was a harrowing experience they could never forget. (JI, p. 59)

The endeavour of writing history from below has attested to be rewarding. It opens up the possibility of articulating new evaluations of the past. Sharpe professes, "History from below retains its subversive aura..." (p. 39). He points out its influence on mainstream history and on revising the standpoints of mainstream historians. Besides, Sharpe studies the potentials of the re-writing of the history of the lives of any people as lived and experienced. This highlights muted chapters of this history and delivers the people's story written by the people. Thus, it has an important role in assisting to amend and expand mainstream political history that is considered 
the only story or the well-known canon:

In 1947, Jewish gangs (the Stern and the Irgun Zvai Leumi) were waging a ruthless terror campaign against both the Mandatory Government and the Arab population of Palestine. (JI, p. 90)

Many examples of this method indicate how the unknown history of parts of any people can be disclosed:

Our beautiful Jerusalem became a city of violence and strife. We live in a state of continuous insecurity. Every few weeks, the city could be shaken by an explosion and immediately the sirens would start wailing, which meant that a curfew was on. ... These conditions became the norm of life in Jerusalem. ...Our American friend Stabler once jokingly described the situation with the words "zamour, toujours zamour" (zamour being the Arabic word for "siren"). (JI, p. 107)

According to Sharpe the approach of "history from below" studies the historical experience of men and women cited in passing in mainstream history, thus it saves the past experience of the majority of the population from negligence:

In those years attacks upon the British troops and civilians by Jewish terrorists were frequent. ... Who but the British had opened the gates of Palestine wide for Jewish immigration?! Who but the British had taxed the poor fellaheen [peasants] out of their land?! Who but the British Mandatory Government had expropriated large tract of land and handed it over to the new settlers?! (JI, p. 109)

Writings of "history from below" have not only provided a body of work which permits us to know more about the past, they have also made it plain that there is a great deal more, much of its secrets still loitering in unmapped and without proof, which could be known:

A Jewish terrorist gang disguised as Arab peasants had placed enormous amounts of explosives in milk cans in the cellar under the southwestern wing of the King David Hotel, which at that time housed several Government departments. That morning the place had been full of Government officials, employees and ordinary citizens who had come on business. Three storeys were blown up and as result no less than ninety persons were under debris. Sari had passed by in a taxi only a few minutes before the explosion. (JI, p. 108)

This eyewitness shows how Jewish gangs used to spread terror in Jerusalem in order to drive out the native Arabs from their land, which is set against mainstream narrative that the Palestinians sold their lands willingly to the Jews. Sharpe suggests that history from below gives way to the recovery of the long forgotten or left out parts of history of many social groups who may have thought that it had lost it or who were ignorant that its history existed. Moreover it offers those reading it with an awareness of their identity, and with a sense of where they came from (Sharpe). It also helps in matters of self-identification by ascertaining the identity of the less privileged or the less powerful. Moreover, it tells what really happened to ordinary people. Notably, history from below has a major role in the formation and development of national identity, affirming that identity is not constructed by rulers or sovereigns or leaders. Sharpe refers to Eugene Genovese's book on black slaves in the pre-Civil War United States and Edward Thompson's work on the English working class. The subject matter for those writers was the socially disadvantaged people who were the main players in their texts. They were able to make a world by themselves and for themselves. Thus they developed as historical actors producing a history that was much neglected. Similarly, Sakakini re-produces major incidents and events in the history of Jerusalem, which were disregarded for political reasons:

The disaster was immense and the Arab population of Jerusalem was deeply shocked. These "modern" methods of terror used by the Jews were still new to us. The deceitful, treacherous way in which the Jewish gangs went about their business we found cowardly and abhorrent. In many other incidents similar to that of the King David Hotel, the Jewish gangs were disguised as British soldiers or policemen and they could thus pass unchecked.

Dumia and I attended the funeral of a young woman who used to work as a typist. She was Hilda Azzam, a pretty, attractive girl in her early twenties. Another ... was Ibrahim Farraj, who left a young widow and two small children. (JI, p. 108)

What the formal historical records left out or did not highlight was that Jerusalem became "the scene of many funerals" (JI, p. 108) because "the firing did not stop at all" (JI, p. 120) hence, it "became a city of violence and strife" (JI, p. 107). Definitely, history from below subverts mainstream narrative, hence rendering an alternative truth. 


\section{Alternative Truth}

Sakakini tells her story from within the walls of history, the walls of the city of Jerusalem. She speaks from a position within history, caught in the active forces of historical change. While there is a decline in favouring authoritative objective history by scholars, Gilligan acknowledges that including women's lives told by women changes how the human story is told:

That year, 1929, Dumia and I for the first time became aware of the political situation in Palestine. The atmosphere was intense. There was a curfew on. Around six o'clock in the evening Mother and both of us would stand behind the garden wall which ran along the main street and watch as armoured cars full of British soldiers rushed past in the empty street. (JI, p. 8)

Similarly, commenting on black female autobiography, which is applicable to Arab women writers, Perkins says "There is less interest in an authoritative history than in the multiplicity of stories that make up that history, told differently by different individuals" (XIII). The events and places that Sakakini brings into her story are culturally and historically important. Hala's autobiographical voice becomes plural, voicing all Jerusalemites, as she is writing and speaking about them at a certain point in history that she has lived and experienced:

Often at night we would hear firing in the mountains and we would try to guess what kinds of gun were being used and where the fighting was taking place. The following morning when peasant women came to sell us fruit and vegetables we would ask them about it. ...Sometimes young peasant men would come carrying huge baskets of fruits. Their eyes were bloodshot and their faces pale as if they had not slept for days. Mother would make coffee for them and father would offer them cigarettes. (JI, p. 58)

She is an eyewitness to history, chronicling her lived experience in her personal record, hence forming a historical counter memory that is subverting and dismantling to the dominant discourse: "I was born in the Old City of Jerusalem, in my maternal grandfather's house"(JI, p. 4). The pre-1948 history is written from the archives of the memory of an individual, in this case a woman who is re-codifying the collective history of her people:

As we were about to leave, after a short visit, we heard a very loud explosion. Soon afterwards bedlam seemed to have broken loose. Quick automatic firing could be heard from every direction, and it would not stop. An hour passed, two hours, three hours and the shooting went on unbroken. It was as though all Jerusalem had become an arena of a fierce battle. By nine o'clock Sari and I could not wait any longer. What had begun as a short, formal visit had dragged on for hours. ...Finally, at about ten o'clock, the shooting calmed down a little and we ventured out. When we came to Jaffa Gate we found quite a number of people, mostly men, who had been stranded downtown like ourselves when the shooting had started four hours before. (JI, p. 109)

The self becomes representative of the collective thus sanctioning the voices, the stories, the histories and memories of her fellow citizens. She has disarmed mainstream history of its authority giving way not only to her story, but for others to tell their own stories of a once lived reality. Furthermore, the individual plight becomes a voice for the distressed muted voice of a whole nation, since she is interlacing her personal affairs with the affairs of the collective. Women were not living on the margins or peripheries of their societies during times of political and social upheavals:

In the following weeks Aunt Melia and her friend, Sit Zuleikha Shihabi, representing the Arab Women's Union, visited tens of bereaved families. My aunt came home with heartrending stories. (JI, p. 108)

Hala Sakakini seizes the complexity of being a Jerusalemite and of being a female and a writer. It derives much of its authority and particularity from the fact that she lived what she was writing about and thus what she is rendering is a documentation of a reality. One of these humiliating incidents was

when the British troops surrounded the town, imposed a curfew and began a house to house search. ... [which] was an excuse for taking vengeance on the population. ... all men were rounded up and taken to the largest square in town. ...they had to squat, one man next to the other, in the sun, for hours on end. Dr. Dides Sr., who was at the time in his late sixties, was not spared. Once the men were safely out of the way, the British troops went into the houses. (JI, p. 59)

This is a recording of an experience, (amongst similar others) that unravels a once lived Jerusalemite reality and, that is delivered according to how Sakakini experienced it, perceived it and projected it. She faces overlapping fronts of struggle that consists in a complex grid of forces ranging from British mandate to Zionist gangs. She is not a detached pensive spectator looking at her world from afar, but she is fused with every bit of what she is narrating, which is deeply entrenched in her consciousness: 
There was a guerilla warfare going on all over Palestine. Our men fought heroically against the well-trained and well-equipped divisions of the British army. Soon heroes' names were on everybody's lips and we used to speak of their exploits with great pride. Remote, obscure villages in Palestine became famous through the bloody, fierce battles that took place in their neighbourhoods. (JI, p. 57)

In Jerusalem and I, Sakakini's process of narration plays a significant role in the text. Jerusalem and I unfolds the predicament of the citizens of Jerusalem or the Jerusalemites along with the plight of a whole nation. The narrative discloses the desperate situation of the displaced citizens to make way for a new nation:

We were a group of schoolgirls and we were naturally talking in Arabic. As we were walking along, European-looking children ran out of the houses on both sides of the street and started shouting at us in broken Arabic: "Go away! This is our country!"

...Like so many other newly-arrived immigrants from Europe and America, ...had come to Palestine with a blind determination to make it their own country - and theirs alone. Of course, they did not want any Arabs around. The indigenous people, the natives, were a nuisance, and the mere sight of them put the newcomers in an ugly mood. (JI, p. 70)

The author delineates at length the anguish of this painful experience. She emphasizes the intersection of the private and the public lives during that politically turbulent time and place. Sakakini makes use of narration, diary entries, and letters from Cairo along with photos and maps to prove what she claims is hers and her people. The letters, photos, maps, certificates and diary entries that Sakakini incorporates in her personal record serve as documents to resist the falsification and distortion in the official record. She weaves it in such a way to become part of the text thus enabling her to destabilize and overthrow the official historical record and validating her story.

Obviously, Sakakini's personal record develops from the need to use personal and collective narratives to document the other side of the history of the struggle and to further a political agenda. Through her personal narrative, Sakakini attempts to build fundamental links with historical records, re-visiting key incidents and events in order to re-read these critical moments. The personal daily experience is projected on the collective one and thus offering to the reader a sense of awareness to grasp larger political issues and struggles. This allows her to reclaim fundamental absences in the master narrative:

Wednesday, April 14 $4^{\text {th }}, 1948$

Lately, ever since the massacre of DeirYasin, we have been thinking seriously of leaving Jerusalem. The most terrible stories have reached us from eyewitnesses who have escaped from this unbelievable massacre. ...pregnant women and children were tortured to death, young women were stripped naked, humiliated and driven through the Jewish quarters to be spit upon by the crowds. The "civilized" Jews are not ashamed of their crime at all and we know that they are capable of repeating it whenever and wherever possible. One day, perhaps very soon, we may be forced to leave our house. I don't like to think of it. (JI, p. 118)

Furthermore, her reality was shaped by her past. Hence, creating a different discourse that subverts dominant postulations and hegemonic modes of comprehension. This mêlée to have power over the historical record is acknowledged as "no less crucial than armed struggle" (Harlow, p. 7). Sakakini projects her past recollections into the present. Her narrative serves as a counter-memory to the master narrative of mainstream colonialist history. Jerusalem \& $I$ is set against the selective memory of the master Western narrative, hence subverting its credibility. For instance,

Monday, January $5^{\text {th }}, 1948$

The eastern wing of Hotel Semiramis was completely destroyed. It was nothing but a heap of rubble. (JI, p. 110)

It is a groundbreaking text trying to save history. She is re-presenting a collective story, giving authority and credibility to it through the incessant re-writing of every bit of life in Jerusalem. Jerusalem turns to be a "narrative" in itself and by itself. Western studies depend on biased historians, where they ignore the existence of Palestinians in Jerusalem (Davis, 1999). It is the story of a whole lived culture with all its details whether in the public or the private realm:

Sunday, March $14^{\text {th }}, 1948$

Today, from early morning, we could see trucks piled with furniture passing by. Many more families from Katamon are moving away, and they are not to blame. 
Who likes to be buried alive under debris?! (JI, p. 115)

Her diaries are a record that registers the story of a real people who lived in a real place: Jerusalem. Definitely, her personal record could be considered as a "cultural autobiography" (Reagon, p. 81) where she is confidently writing her city to emphasize the existence of this culture with real people living through it, thus keeping it alive:

All day long you could see people carrying their belongings and moving from their houses to safer ones in Katamon or to another quarter altogether. They reminded us of pictures we used to see of European refugees during the war. ... The rumour spread that leaflets had been dropped by the Jews saying that they would make out of Katamon one heap of rubble. Whenever we saw people moving away we tried to encourage them to stay. We would tell them: "you ought to be ashamed to leave. This is just what the Jews want you to do; you leave and they occupy your houses and then one day you will find that Katamon has become another Jewish quarter." (JI, p. 111)

The re-writing of these intact collective personal experiences is an act of resistance against cultural annihilation. It is her way of "staying alive" (Hooks, p. 431). Accordingly, Sakakini's continuous correlation of the personal with the collective renders her personal record as a text of cultural survival:

Monday, April 26 $6^{\text {th }}, 1948$

Conditions in Jerusalem are quickly developing from bad to worse and everybody's nerves are on edge. All owr friends are surprised that we have remained in Katamon up till now. ...Like the other day, we were awakened at twelve midnight by heavy firing and strong explosions. We put on our clothes and stayed up until the morning as the firing did not stop at all. It was an awful night. (JI, p. 120)

Friday, April $30^{\text {th }}, 1948$

....an attack on Katamon began. It was stronger than ever. The firing was heavy and continuous and it sounded so very near...

The Jews had come in very large numbers and they were trying to surround Katamon and besiege it. Already fifteen of our fighters had been killed and thirty wounded.

We immediately began to load the bags into the car... (JI, p. 121)

Certainly, the process of recollection is nothing but a re-reading of history, offering an alternative truth, which will subvert the story of the powerful.

\section{Conclusion}

Evidently, Jerusalem and $I$ is a text that seizes the history of a given period of time through the life of a Jerusalemite. Sakakini's epic is set against a background of Palestine's national history. She selects the historical facts that are pertinent to her message in order to support her idea. For Sakakini, the nation comes before the self. Her nationalistic ambitions are her primary goal and her main preoccupation. In reclaiming the nation or the whole, she will redeem the self. In having the power of representation, she is sharing the predicament of all Jerusalemites or Palestinians while subverting mainstream narrative to offer an alternative truth.

Moreover, Sakakini, as a Jerusalemite autobiographer locates her personal record within the tangible historical events of Palestine. Her personal record explains the plight of the entire nation, and the personal with the collective run effortlessly and continuously into each other. Sakakini is absorbed in her personal life experience yet is involved in the life of her community weaving them together to become one whole. Her personal reality becomes larger and wider than her limited self, since her narrative evolves to be both personal and collective. Her "I" is anchored in the communal all. The personal and the collective are inter-dependent. Theories of historical sociology and collective remembering describe autobiographical memory as the means of re-creating historical reality (Halbwachs). Thus her personal narrative is given a historical value. It is a documentary. Hers is a national allegory where she associates the personal and the political delivering a sense of a collective identity.

Certainly, Sakakini's Jerusalem and $I$ is an act of resistance. It is a resistance that is active and subversive in a way very special to her circumstances and inclinations. It is this kind of resistance that offers an "alternative truth", which dismantles mainstream narratives, through writing "history from below". Hala Sakakini's is a quest for a lost place not a personal gendered quest; it is a collective discourse of belonging.

\section{Reference}

Ahmad, A. (1986). James's Rhetoric of Otherness and the National Allegory. Social Text, 3-28.

Al Nowaihi, M. (2001). Resisting Silence in Arab Women's Autobiographies. International Journal of Middel East Studies, 33, 477-502. https://doi.org/10.1017/S0020743801004019 
Al Zayyat, L. (1994). On Political Commitment and Feminist Writing.

Al Zayyat, L. (1996). The Search: Personal Papers. (S. Bennett, Trans.) London: Quartet Books.

Anderson, B. (1998). The Spectre of Comparisons: Nationalism, South Asia and the World. London: Verso.

Badr, L. (1990). A Compass for the Sunflower. (C. Cobham, Trans.) London: The Women's Press.

Bakhtin, M. M. (1992). The Dialogue Imagination: Four Essays. In M. Holquist (Ed.), (C. Emerson, \& M. Holquist, Trans.) Austin: University of Texas Press.

Bemong, N., \& Boghart, P. (2010). Bakhtin's Theory of the Literary Chronotype: Reflections, Applications, Perspectives. In P. Borghart, M. De Dobbeleer, K. Demoen, K. De Temmerman, \& B. Keunen (Eds.), Bakhtin's Theory of the Literary Chronotype: Reflections, Applications, Perspectives. Gent: Academia Press.

Bhabha, H. (1994). The Location of Culture. London: Routledge.

Chatterjee, P. (1993). The Nation and Its Fragments: Colonial and Postcolonial Histories. Princeton: Princeton University Press.

Davis, R. (1999). The Growth of the Western Communities, 1917-1948. In S. Tamari (Ed.), Jerusalem 1948: The Arab Neighborhoods and their Fate in the War.

Enderwitz, S. (2002). Palestinian Autobiographies: A Source for Women's History? In M. Marin, \& R. Deguilhem (Eds.), Writing the Feminine: Women in Arab Sources (pp. 49-72).

Fox-Genovese, E. (1988). My Statue, My Self: Autobiographical Writings of Afro-American Women. In S. Benstock (Ed.), The Private Self: Theory and Practice of Women's Autobiogrophical Writings (pp. 62-89).

Freidman, S. (1988). Women's Autobiographical Self: Theory and Practice. In S. Benstock (Ed.), The Private Self: Theory and Practice of Women's Autobiographical Writings (pp. 34-62).

Gaston, B. (1969). The Poetics of Space. (M. Jolas, Trans.) Boston: Beacon Press.

Gilligan, C. (1993). Another Voice: Psychological Theory and Women's Development. Cambridge, MA.

Golley, N. Reading Arab Women's Autobiographies, Shahrazad Tells her Story. Austin: University of Texas Press.

Gunn, J. V. (1992). A Politics of Experience: Leila Khaled's My People Shall Live: The Autobiography of a Revolutionary. In S. Smith \& J. Watson (Eds.), De-colonizing the Subject: The Politics of Gender in Women's Autobiography (pp. 65-80).

Halbwachs, M. (1980). On Collective Memory. NY: Harper and Row.

Harlow, B. (1987). Resistance Literature. New York: Methuen.

History from Below. (2006). The Times Literary Supplement (TLS), Art \& Commentary. Retrieved from http://www.the-tls.co.uk/articles/private/history-from-below/

Hooks, B. (1998). Writing Autobiography. In S. Smith, \& J. Watson (Eds.), In Women, Autobiography, Theory: A Reader (pp. 429-432). Wisconsin: University of Wisconsin Press.

Jameson, F. (1986,). Third World Literature in the Era of Multinational Capitalism. Social Text, 65-88. https://doi.org/10.2307/466493

Jameson, F. (1988). Cognitive Mapping. In C. Nelson \& L. Grossberg (Eds.), Marxism and the Interpretation of Culture (pp. 347-357). https://doi.org/10.1007/978-1-349-19059-1_25

Khalifeh, S. (2002). My Life, Myself and the World. Al Jadid, 8(39), 11.

Lionnet, F. (1989). Autobiographical Voices: Race, Gender, and Self-Portraiture. Ithaca: Cornell University Press.

Milani, F. (1990). Veiled Voices: Women's Autobiographies in Iran. In A. Najmabadi (Ed.), Women's Autobiographies in Contemporary Iran (pp. 1-16).

Mohanty, C. T. (1991). Under Western Eyes: Feminist Scholarship and Colonial Discourses. In C. T. Mohanty, A. Russo, \& L. Torres (Eds.), Third World Women and the Politics of Feminism (pp. 51-80).

Perkins, M. (2000). Autobiography as Activism: Three Black Women of the Sixties. Jackson: University Press of Mississippi. 
Popular Memory Group. (1982). Popular Memory: Theory, Politics, Method. In R. Johnson, G. McLennan, B. Schwartz, \& D. Suttow (Eds.), Making Histories: Studies in History, Writing and Politics (pp. 205-252).

Reagon, B. J. (1982). My Black Mothers and Sisters or On Beginning a Cultural Autobiography. Feminist Studies, 8, 81-95.

Said, E. (1984). The Mind of Winter: Reflection on Life in Exile. Harper's Magazine, 49-55.

Said, E. (1990). Reflections on Exile. In R. Fergusson, M. Gever, T. T. Minh-ha, \& C. West (Eds.), Out There: Marginalization and Contemporary Culture (pp. 357-66).

Said, E. (1995). The Politics of Dispossession: the Struggle for Palestinian Self-Determination 1969-1995. London: Vintage.

Sakakini, H. (1990). Jerusalem and I: A Personal Record. Amman: The Economic Press Co.

Saldivar, R. (1990). Chicano Narrative: the Dialectic of Difference. Wisconsin: The University of Wisconsin Press.

Seyhan, A. (2001). Writing Outside the Nation. Princeton: Princeton University Press.

Shaaban, B. (1991). Both Right and Left Handed: Arab Women Talk about their Lives. Bloomington: Indiana University Press.

Sharpe, J. (2001). History from Below. In P. Burke (Ed.), New Perspective on Historical Writing (pp. 25-42).

Smith, S. (1993). Who's Talking / Who's Talking Back? The Subject of Personal Narrative. Signs, 18(2), 392-407. https://doi.org/10.1086/494799

Smith, S. (1996). Getting a Life: Everyday uses of Autobiography. In S. Smith, \& J. Watson (Eds.), Minnesota: University of Minnesota Press.

Smith, S. (1998). Autobiographical Manifestos. In S. Smith, \& J. Watson (Eds.), In Women, Autobiography, Theory: A Reader (pp. 433-440). Wisconsin: The University of Wisconsin Press.

Thompson, E. (1966). History from Below. Times Literary Supplement, 279-280.

Tzoreff, M. (2000). Fadwa Tuqan's Autobiography: Restructuring a Personal History into the Palestinian National Narrative. In B. Shoshan (Ed.), Discourse on Gender/Gendered Discourse in the Middle East (pp. 57-77).

Watts, J. (1989). Black Writers from South Africa: Towards a Discourse of Liberation. London: Macmillan. https://doi.org/10.1007/978-1-349-20244-7

\section{Note}

Note 1. Brecht's poem offers a direct statement of the need for an alternative perspective to reading history. This concept was put into action when E.Thompson formed the concept "history from below". From thence, historians with different ideologies (not necessarily Marxist) and intellectual traditions implemented "history from below" as a means of formulating new or even different evaluations of the past as present in mainstream narratives. Such approach places a social event within its full cultural context. It dismantles formal historical records. (Sharpe)

\section{Copyrights}

Copyright for this article is retained by the author, with first publication rights granted to the journal.

This is an open-access article distributed under the terms and conditions of the Creative Commons Attribution license (http://creativecommons.org/licenses/by/4.0/). 